\title{
Patterns of Diversity and Distribution of Arboreal Social Bees' Beehives within Chimpanzees' Home Range in a Forest-Savanna Mosaic (Comoé National Park, Côte d'Ivoire)
}

\author{
NA SORO ${ }^{1}$, J LAPUENTE ${ }^{2}$, NA KONÉ $E^{3}$, K YÉO $^{4}$, S KONATÉ $^{5}$ \\ 1 - Nangui Abrogoua University, UFR des Sciences de la Nature (UFR SN), Research Station in Ecology of Lamto scientific Reserve, Research \\ Station in Ecology of the Comoé National Park, Abidjan, Côte d'Ivoire \\ 2 - Research Station in Ecology of the Comoé National Park, Abidjan, Côte d’Ivoire; Animal Ecology and Tropical Biology, Biozentrum, \\ Universität Würzburg Tierökologie und Tropenbiologie (Zoologie III), Würzburg, Germany \\ 3 - Nangui Abrogoua University, UFR des Sciences de la Nature (UFR SN), Research Station in Ecology of the Comoé National Park, Abidjan, \\ Côte d'Ivoire \\ 4 - Nangui Abrogoua University, UFR des Sciences de la Nature (UFR SN), Research Station in Ecology of Lamto scientific Reserve, Abidjan, \\ Côte d'Ivoire
}

5 - Nangui Abrogoua University, UFR des Sciences de la Nature (UFR SN), Abidjan, Côte d'Ivoire

\section{Article History \\ Edited by \\ Kleber Del-Claro, UFU, Brazil \\ Received 27 February 2019 \\ Initial acceptance 18 June 2019 \\ Final acceptance 02 July 2019 \\ Publication date 14 November 2019}

\section{Keywords}

Bee species, honey, chimpanzee, nesting tree, habitat type, Comoé National Park.

\section{Corresponding author}

Nicodénin Angèle Soro

Nangui Abrogoua University

02 BP 801, Abidjan 01, Côte d'Ivoire.

E-Mail: nicodenin@gmail.com

\begin{abstract}
The goal of this study was to explain the patterns of diversity and distribution of arboreal social bees nesting in forests of the Comoé National Park, within the homeranges of wild chimpanzees, consumers of their honey. Investigations were done using a total of sixteen plots of one hectare each, established in three habitat types (mature forest island, secondary forest island and gallery forest). The diversity and distribution of arboreal social bees was assessed using visual searches. The exploitation of the beehives of these bees by chimpanzees was also evaluated using honey dipping tools as indicators. Five bee species belonging to two tribes, namely the Meliponini (Meliponula ferruginea, Meliponula togoensis, Meliponula bocandei, Hypotrigona gribodoi) and the Apini (Apis mellifera) were collected. Furthermore, frequent exploitation of the honey of stingless bees by chimpanzees was observed, excepted for $\mathrm{H}$. gribodoi. Beehives of Meliponula ferruginea were identified as the most exploited ones by chimpanzees. A total of 114 beehives were found in the established plots leading to an estimated density of 2.4 beehives/ha within the study area. Among the surveyed habitats, mature forest island was found to harbor the highest beehives' density (4.2 beehives/ha), followed respectively by secondary forest island (1.9 beehives/ha) and gallery forest (1.1 beehives/ha). Finally, all bee species were found nesting in cavities of trees with a DBH ranging from 15 to $87.3 \mathrm{~cm}$, with a special preference for Dialium guinneense. However, the DBH of the nesting trees and the beehives' height measured from the ground level, were found not significantly influencing the honey exploitation by chimpanzees. In sum bee species diversity and distribution might be the most important variables in the survival of chimpanzees within forest-savanna mosaic landscape.
\end{abstract}

\section{Introduction}

Invertebrates are included in the diet of many primates (Redford, 1987; Pruetz, 2006). Within the primates, chimpanzees consume mainly social insects such as termites (Macrotermes spp., Cubitermes spp., Thoracotermes spp.), ants (Dorylus spp., Oecophylla longinoda, Camponotus spp.) and bees/honey (Apis mellifera and the Meliponini) (O’Malley \& Power, 2012). 
These invertebrates offer a large, clumped biomass and/or a high nutritional pay-off (McGrew, 2001; Deblauwe et al., 2003).

In African savannas, where chimpanzees have been studied extensively, it has been demonstrated that the consumption of insects by chimpanzees occurs seasonally. In Tanzania and Senegal, respectively located in eastern and western Africa, termites were for example found mainly included in their diet during rainy seasons (McBeath \& McGrew, 1982; Goodall, 1986), while bees and honey were eaten during the late dry season (Pruetz, 2006). The consumption of honey by chimpanzees has been reported in many sites across Africa, suggesting the importance of bees as a significant food resource for these primates (McGrew, 1992; Sanz \& Morgan, 2007; 2009). In fact, some populations of the chimpanzee subspecies have been found to prey upon brood and stored honey of Apini and Meliponini (Sommer et al., 2012). Many of these studies revealed the use of tools by the chimpanzees to collect the honey (Crickette \& David, 2008; Boesch et al., 2009; McLennan, 2011; Sommer et al., 2012). Indeed, apart from humans, only orangutans (van Schaik, 2004) and chimpanzees (Sanz \& Morgan, 2009) gain access to beehives using tools. Honey gathering using tools typically involves inserting probes in beehives. These probes can be modified to obtain frayed ends for honey dipping (Sommer et al., 2012). Indeed, such tools with brush-tips allow collecting up to six times more honey than those with unmodified tips (Tutin et al., 1995).

Like other great ape taxa, the western chimpanzee has come under enormous human pressures. For example, about $90 \%$ of the Ivorian chimpanzee population was lost mainly due to anthropogenic disturbances (Campbell et al., 2008). In this country, the chimpanzee populations are highly endangered since only those found in the Taï and Comoé national parks are considered as viable (Hoppe-Dominik, 1991; Marchesi et al., 1995). Recently, studies combining the use of camera trap videos and the indirect signs' observations along transects, revealed the importance of honey consumption by the chimpanzees of the Comoé National Park (Lapuente et al., 2016). However, a lack of information was identified on (i) the diversity of bee species exploited by these chimpanzee populations, (ii) the density of beehives within the chimpanzees' habitats and (iii) the plant species on which these beehives are established.

Bees are recognized to exhibit a diverse array of nesting strategies closely dependent to the part of the habitat type, the nature of the used substrate to nest and the material required for the construction of the beehive (Roubik, 2006).

The most important role of these beehives is to protect colonies against environmental perturbations by maintaining a specific microclimate for brood development (Roubik, 2006; Siqueira et al., 2012; Pavithra et al., 2013). Social bees from the Apidae family, including honeybees, bumblebees, and stingless bees, often use pre-existing cavities of trees, ground and termite mounds for building their beehives (Potts et al., 2005; Roubik, 2006; Eardley et al., 2010).
We started this research with the following questions in mind: (1) which social bees' species produce honey consumed by chimpanzees of the Comoé National Park? In addition, (2) is there a selection of tree species by bees, for nidification within habitats? Finally, (3) does the habitat type has an effect on the availability of tree species with suitable nesting sizes for bees?

The overall goal of this study was to determine the patterns of diversity and distribution of arboreal social bee species' beehives within habitats of a Sudano-guinean savanna zone in order to assess their exploitation by the dwelling chimpanzee species. Specifically, it aimed at (i) assessing the diversity of arboreal social bees nesting in the homeranges of chimpanzees within the Comoé National Park, (ii) determining the distribution and density of the beehives of these bee species within these habitats, (iii) identifying the preferred plant/tree species and the height of beehive' positioning in the identified bee species.

\section{Materials and methods}

Description of study area

This study was conducted in the Comoé National Park (CNP). This park covers around $11,500 \mathrm{~km}^{2}$. It is a UNESCO World Heritage site and a Biosphere Reserve, located in the north-eastern part of Côte d'Ivoire in West Africa, between the $8^{\circ} 30^{\prime}-9^{\circ} 40^{\prime} \mathrm{N}$ and the $3^{\circ} 10^{\prime}-4^{\circ} 20^{\prime} \mathrm{W}$. The CNP is covered by $91 \%$ of savanna habitats while gallery forests and forest islands cover around $8.4 \%$ of this park (Mühlenberg et al., 1990). These forests are the main chimpanzee habitats within this park.

The climate of the CNP is warm and dry, with a mean temperature of $27^{\circ} \mathrm{C}$ and an average annual precipitation oscillating around $1090 \mathrm{~mm}$ (Hennenberg, 2005). From November 2017 to July 2018, this study was concentrated on a study area of $900 \mathrm{~km}^{2}$ that the Comoé Chimpanzee Conservation Project established since 2014 in the South-Western sector of the park. During this study, three forest types, which respective characteristics are described below, were surveyed:

- Mature forest island (MFI): this habitat is an old, never exploited semi-deciduous forest island submitted to a natural evolution which is now close to the final stages (aging, mortality) of the silvigenetic cycle. It is an open pool of trees, up to $35 \mathrm{~m}$ in height, with a recovery of at least $40 \%$ (Kouassi et al., 2014). This habitat is dominated by several species belonging to numerous plant families: Malvaceae (Ceiba pentandra, Cola cordifolia), Combretaceae (Anogeissus leiocarpus), Moraceae (Antiaris toxicaria, Milicia excelsa), Oleaceae (Schrebera arborea), Zygophyllaceae (Balanites wilsoniana), Ulmaceae (Celtis zenkeri, C. integrifolia), Fabaceae (Dialium guineense), Ebenaceae (Diospyros mespiliformis, D. abyssinica), Sapotaceae (Pouteria alnifolia, Manilkara obovata, M. multinervis), Dichapetalaceae (Tapura fischeri) (Lauginie, 2007). 
The herbaceous layer is dominated by Poaceae family (Oplismenus hirtellus, Cyrtococcum chaetophoron, Olyra latifolia and Centotheca lappacea). This layer is sparse and has a height between 0 and $2 \mathrm{~m}$ (Kouassi et al., 2014).

- Secondary forest island (SFI): which is also a semideciduous forest island that has undergone different forms of anthropogenic disturbances at a given period; but regenerated over years (Aubréville, 1949). This habitat is also dominated by most of the same plant species of the mature forest island; but in a lower density. However, other species were exclusively encountered in this habitat (i.e. Lannea welwitschii, Tetrapleura tetraptera, Zanthoxylum zanthoxiloides, Afraegle paniculata) and woody liana belonging to two families; namely the Malpighiaceae (Flabellaria paniculata) and the Apocynaceae (Alafia scandens, Landolphia hirsuta, Secamone afzelii, Baissea zygodioides, Cryptolepis sanguinolenta) (Lauginie, 2007). The invasive plant species Chromolaena odorata (Asteraceae) is also abundant in this habitat.

- Gallery forest (GF): This habitat is located along the Comoé river. It presents a relatively closed pool of trees with a higher closed canopy of more than $30 \mathrm{~m}$ high. The recovery is between 40 and $70 \%$ for the upper stratum (Kouassi et al., 2014). The dominant tree species is Cynometra megalophylla (Caesalpiniaceae). However, other plant species are found in this habitat. They mainly belong to the families Euphorbiacece (Drypetes floribunda, D. gilgiana, Dichapetalum madagascariensis,), Rubiaceae (Oxyanthus recemosus), Fabaceae (Dialium guinnense), Loganiaceae (Strychnos sp.), Linaceae (Hugonia planchonii) and Annonaceae (Xylopia parvifolia). The herbaceous layer of this habitat dominated by three plant families namely Acanthaceae (Elytraria marginata), Poaceae (Acroceras zizanoides) and Cyperaceae (Hypolytrum heteromorphum). Its characteristics are identical to those of the forest island.

\section{Sampling design}

Bee beehives survey

Sixteen plots of one hectare each $(100 \mathrm{~m} \times 100 \mathrm{~m})$ were established within each of the surveyed habitats. Visual searches of arboreal social bees'beehives were conducted in each plot, using a pair of binoculars when needed.

Trees with diameter at breast height $(\mathrm{DBH}) \geq 15 \mathrm{~cm}$, were considered as potential nesting ones (Darchen, 1972; Tornyie \& Kwapong, 2015). For every encountered beehive, the tree DBH and height at which the entrance of bees is located above the ground level, were recorded using a measuring tape. For trees with large buttresses, the DBH measurements were taken just above these buttresses. The height of the bees' nests above the ground level was measured when located less than 6 $\mathrm{m}$ and just estimated when superior to this distance.
The density of potential nesting trees (with a DBH $\geq$ $15 \mathrm{~cm}$ ) was calculated per habitat and per species surveyed. The density of beehives per species was also determined in these established plots. Some beehives were certainly missed, especially those located high in the canopy.

The field surveys were done during the sunny days in order to make easier the observation of foraging bees' flying in and out of their respective beehives. Bees' traffic and beehives entrances tubes were then searched in bases, on trunks and branches of all dead and live trees. The encountered beehives were all photographed and geo-referenced with a handheld GPS. For each beehive found, samples of worker individuals were collected using an insect aerial net and stored in Eppendorf tubes containing $70 \%$ ethanol for future identification. The species identification of colonies nesting high in inaccessible tree trunks was done in situ using a pair of binoculars.

When a beehive was found in a tree cavity, this tree was identified at the species or morphospecies level. The identification of plant species was confirmed by the National Floristic Centre located of the Félix Houphouët-Boigny University (Abidjan, Côte d'Ivoire).

\section{Identification of social bees which honey is exploited by chimpanzees}

A recent study by Lapuente et al. (2016) showed the use of tools for the consumption of honey by the chimpanzee communities of the CNP. Based on these results, the chimpanzee honey dipping tools were used as indicators of beehives exploited by these primates. Comoé chimpanzees have been found to leave honey collection tools inserted in the beehive entrance or at the base of the trees where the beehive has been exploited. Therefore, we determined which beehives had been exploited by chimpanzees by the presence of used tools and traces of the exploitation such as honey dripping from the beehive entrance or remains of the honeycombs with chimpanzee teeth marks. We identified the used chimpanzee tools by the following characteristics: a portion of a branch cut to a determined length, stripped from leaves and lateral branches, often with a brush tip made by chimpanzees using their teeth and clear signs of wear from being used, such as frayed or blunt ends, remains of honey or wax, dirt left by the hand grip.

\section{Identification of bees}

Bees were first mounted, labeled and then identified using the determination keys of Eardley (2004) and (Eardley et al., 2010) under a low-power stereo binocular microscope. The reference collection of bee species of Central Côte d'Ivoire collected in the Lamto Scientific Reserve was also used during this work. Voucher specimens of all the identified species are available at the Lamto Research Station in Ecology. 


\section{Statistical analysis}

The sampling efficiency of bees was tested by constructing sample-based species accumulation curves and recording the mean similarity between plots of the same habitat type. Indeed, accumulation curves were produced to show the evolution of the species richness in relation to the sampling effort. Using the program EstimateS 8.0.0 (Robert K. Colwell, Department of Ecology \& Evolutionary Biology, University of Connecticut, Storrs, CT 06869-3043, USA; Website: http://purl.oclc.org/estimates), the observed and estimated species accumulation curves, respectively Sobs and Chao2, were constructed after randomizing 500 times the sample in order to ensure the statistical representation of the target assemblage. The diversity of bees' assemblages and its evenness are measured by Simpson's index. The Bray-Curtis index was calculated for the measurement of the $\beta$-diversity on one hand and the determination of the similarity of species composition between plots of each habitat type on the other hand. Based on the species composition of the surveyed habitats, a hierarchical Ascending Classification (HAC) was performed in order to test the similarity them. These indexes were run on Paleontological STatistics (PAST) version 3.09 (Hammer et al., 2001) at a significance level of 0.05 . Levene's test for homogeneity of variance was used to test the distribution of our data before comparison between habitats. Due to the non-normal distribution of data and the heterogeneity of variances, non-parametric multivariate analysis of variance Kruskal-Wallis and post hoc test (pairwise Mann-Whitney) was used for comparison.

\section{Results}

\section{Overall taxonomic structure of the observed bee species}

A total of five bee species, belonging to the family Apidae, were found being regularly exploited by Comoé chimpanzees. Four of these species belong to three genera of Meliponini, the stingless bees (Hypotrigona gribodoi Magretti 1884, Meliponula ferruginea Lepeletier 1836, Meliponula bocandei Spinola 1853, Meliponula togoensis Stadelman 1895) and one to the Apini, the honeybees (Apis mellifera Latreille 1804).

\section{Sampling efficiency during this study}

The accumulation curves of the estimated and observed species richness were similar in all the surveyed habitats (Fig 1), suggesting a good estimate of the expected species richness of these habitats. Indeed, $100 \%$ of the expected species of each of the surveyed habitat were sampled (Table 1).

Table 1. Metrics of arboreal social bees' diversity in the visited habitats.

\begin{tabular}{llllll}
\hline $\begin{array}{l}\text { Habitat } \\
\text { Types }\end{array}$ & $\begin{array}{l}\text { Species } \\
\text { richness }\end{array}$ & $\begin{array}{l}\text { Sampled } \\
\text { Coverage }\end{array}$ & $\begin{array}{l}\text { Simpson's } \\
\text { Index }\end{array}$ & $\begin{array}{l}\text { Evenness's } \\
\text { Index }\end{array}$ & Abundance \\
\hline MFI & 5 & 100 & 0.76 & 0.91 & 67 \\
SFI & 5 & 100 & 0.56 & 0.62 & 30 \\
GF & 5 & 100 & 0.73 & 0.84 & 17 \\
\hline
\end{tabular}

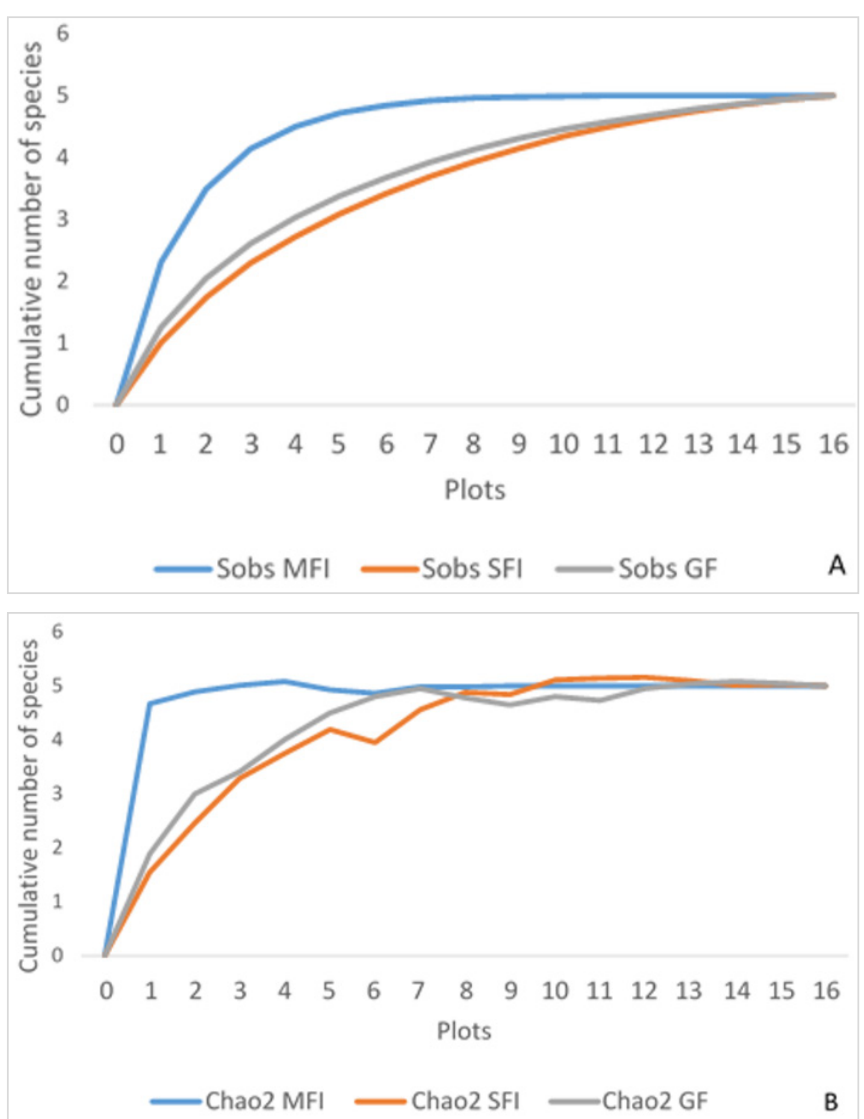

Fig 1. Accumulation curves of the observed (A) and estimated species richness $(\mathrm{B})$ in the visited habitats. Abbreviations: $\mathrm{FI}=$ mature forest island; $\mathrm{SFI}=$ secondary forest island, $\mathrm{GF}=$ Gallery Forest.

Species richness and species diversity of the recorded bees

Five bee species (H. gribodoi, M. ferruginea, $A$. mellifera, $M$. bocandei and $M$. togoensis) were all collected in each of the surveyed habitats. However, different values of Simpson and Evenness indexes were obtained for these habitats. The highest values of these indexes were found for the mature forest island, followed by the gallery forest and the secondary forest island. Furthermore, the Bray-Curtis index based on the species composition of habitats, showed an important similarity between the mature forest island and the secondary forest island (Fig 2).

\section{Abundance and distribution of the beehives of arboreal social bee species exploited by chimpanzees}

A total of 114 beehives were recorded within all the surveyed habitats; 95 belonging to the stingless bees and 19 to the honeybees. The highest mean beehive density was observed in stingless bees ( 2 beehives/ha); while only 0.4 beehives/ha was registered in the honeybees. In terms of beehives'density and abundance at the habitat level, statistical analyses revealed significant differences (Kruskal-Wallis test: $\chi^{2}=6.79 ; \mathrm{df}=2 ; \mathrm{p}=0.03$ ), with a decrease ranking going from the mature forest island to the gallery forest through the secondary forest island (Table 2). 


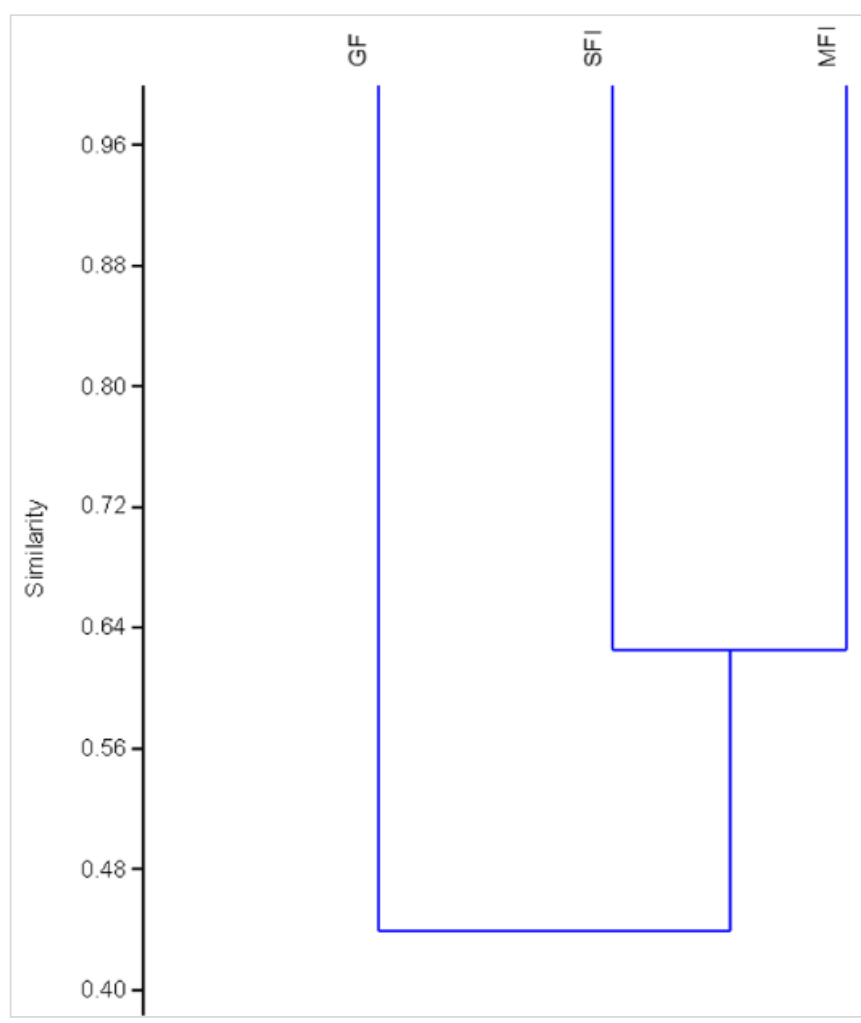

Fig 2. Similarity of species composition of the visited habitats based on Bray-Curtis index. Abbreviations: FI = mature forest island; SFI $=$ secondary forest island, $\mathrm{GF}=$ Gallery Forest.

A total of 36 beehives (roughly $32 \%$ of the total recorded ones) were found with chimpanzees' honey exploitation tools. Most of the beehives exploited by chimpanzees were found in stingless bees (i.e. $89.19 \%$, $\mathrm{n}=32)$. In contrast, only $11.11 \%(\mathrm{n}=4)$ of beehives exploited by chimpanzees were in honeybees. At the habitat level, 22 exploited beehives were observed in the mature forest island while 8 were found in the gallery forest and 6 in the secondary forest island. The most exploited bee species by chimpanzees was $M$. ferruginea respectively followed by $M$. bocandei, M. togoensis, $H$. gribodoi and A. Mellifera. In contrast, the highest number of non-exploited beehives were observed in H. gribodoi, respectively followed by A. mellifera, $M$. togoensis, M. ferruginea and M. bocandei (Fig 3).

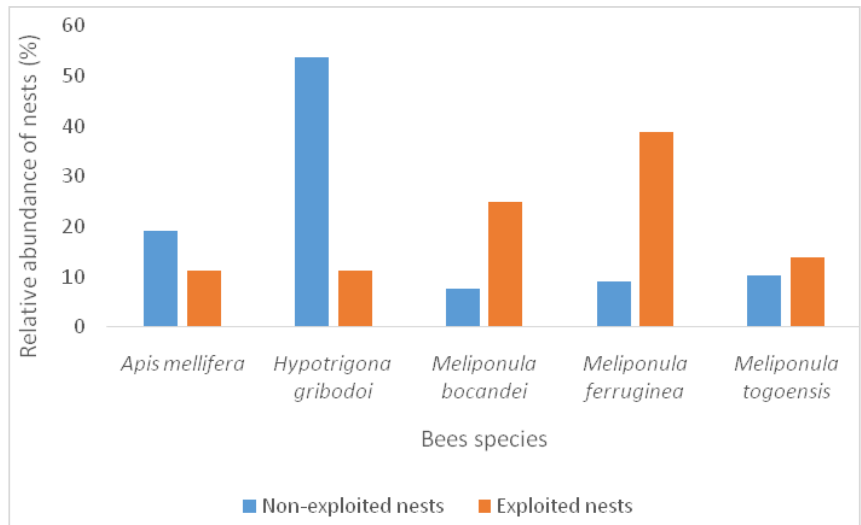

Fig 3. Bee species-specific relative abundance of nests exploited and non-exploited by chimpanzees.
Availability of the resource provided by bees to chimpanzees and the potential nesting trees

We observed six aggregations of beehives for $H$. gribodoi with a maximum of seven beehives observed in the same dead tree. On the other hand, only one case of aggregation was observed for M. ferruginea, with two beehives found on Dialium guinneense. Concerning secondary forest island, we found the highest abundance of beehives for $\mathrm{H}$. gribodoi within the mature forest island and the secondary forest island. On the other hand, in the gallery forest, the beehives of $M$. ferruginea were the most abundant (Table 3). Moreover, in the mature forest island, $M$. bocandei had the highest number of exploited beehives ( $\mathrm{n}=7$ ), while $M$. ferruginea had the highest number of exploited beehives in the gallery forest $(n=6)$.

Table 2. Densities of bees' beehives and potential nesting trees in the three habitats sampled.

\begin{tabular}{llll}
\hline \multirow{2}{*}{ Habitats } & \multicolumn{3}{c}{ Densities } \\
\cline { 2 - 4 } & $\begin{array}{l}\text { Total observed } \\
\text { beehives }\end{array}$ & Beehives/ha & $\begin{array}{l}\text { Potential nesting } \\
\text { trees/ha }\end{array}$ \\
\hline $\begin{array}{l}\text { Mature Forest } \\
\text { Island }\end{array}$ & $67^{\mathrm{a}}$ & $4.2^{\mathrm{a}}$ & $98.8^{\mathrm{a}}$ \\
$\begin{array}{l}\text { Secondary } \\
\text { Forest Island }\end{array}$ & $30^{\mathrm{b}}$ & $1.9^{\mathrm{b}}$ & $58^{\mathrm{b}}$ \\
Gallery Forest & $17^{\mathrm{c}}$ & $1.1^{\mathrm{b}}$ & $94.6^{\mathrm{a}}$ \\
\hline
\end{tabular}

The highest density of bee-nesting potential trees was found in the mature forest island ( 98.8 trees/ha) followed by the gallery forest $(94.6$ trees/ha) and the secondary forest island (58 trees/ha). These habitat-specific densities were found significantly different from a forest type to another (KruskalWallis test: $\left.\chi^{2}=16.72 ; \mathrm{df}=2 ; \mathrm{p}<0.05\right)$. Mann-Whitney pairwise test indicated a significant difference between the density of bee-nesting potential trees of the visited habitats (Table 2).

Table 3. Values in brackets represent the number of beehives exploited by chimpanzees for each bees species in the habitats.

\begin{tabular}{lllll}
\hline \multirow{2}{*}{ Bee species } & \multicolumn{4}{c}{ Habitats } \\
\cline { 2 - 5 } & MFI & SFI & GF & $\begin{array}{l}\text { Total } \\
\text { and RA }\end{array}$ \\
\hline Apis mellifera & $10(3)$ & $5(1)$ & $4(0)$ & $19(4)$ \\
Hypotrigonagribodoi & $26(3)$ & $19(1)$ & $1(1)$ & $46(5)$ \\
Meliponula bocandei & $10(7)$ & $2(1)$ & $3(1)$ & $15(9)$ \\
Meliponula togoensis & $9(4)$ & $2(1)$ & $2(0)$ & $13(5)$ \\
Meliponula ferruginea & $12(5)$ & $2(2)$ & $7(6)$ & $21(13)$ \\
Total & $67(22)$ & $30(6)$ & $17(8)$ & $114(36)$ \\
\hline
\end{tabular}

Beehives' availability on tree species and their potential exploitation by chimpanzees

Beehives of arboreal bee species were encountered on 17 tree species during this study (dead trees were not taken into account). These species belong to 9 plant families 
and 15 genera. Most of the beehives were found on trees of the Leguminoseae family (i.e. Dialium guinneense, Albizia adianthifolia, A. zygia, Tamarindus indica and Tetrapleura tetraptera, Cynometra megalophylla).

On the 114 observed beehives, 91 were found on living trees and 23 on dead ones. Of the 91 beehives found on living trees, 33 were exploited. On the other hand, among the 23 beehives found in cavities of the dead woods, only 3 beehives were exploited by chimpanzees. The highest abundance of beehives was found in the cavities of Dialium guinneense and Manilkara multinervis. These main plant species were respectively followed by Celtis integrifolia, Albizia adianthifolia, Cynometra megalophylla, Anogeissus leiocarpus and Vitex sp.. The lowest number of bee beehives were found in cavities of Albizia zygia, Tetrapleura tetraptera, Liana, Vitellaria paradoxa, Antiaris toxicaria, Ficus ingens, Ficus sp., Diospyros mespiliformis and Cola gigantean (Table S1).

The number of tree species on which beehives were encountered was higher in mature forest island (13 species, 12 genera, 7 Families) than the secondary forest island (6 species, 6 genera, 5 families) and the gallery forest ( 6 species 6 genera, 4 families). Dialium guinneense was identified as the main nesting tree species of the mature forest island. In the secondary forest island, Manilkara multinervis is the main plant species preferentially chosen by bee species for the establishment of their beehive (Table S1). Cynometra megalophylla is the most important plant species supporting the highest number of beehives within the gallery forest. Moreover, a high significant difference was found between the total number of observed trees and the number of trees on which bee nest exploited by chimpanzees were found in the different habitats (Mann-Whitney test: mature forest island: $\chi^{2}=35, \mathrm{df}=1, \mathrm{p}<0.05$; secondary forest island: $\chi^{2}=45.5, \mathrm{df}=1$, $\mathrm{p}<0.05$; gallery forest: $\left.\chi^{2}=48.5 ; \mathrm{df}=1 ; \mathrm{p}<0.05\right)$ (Table $\mathrm{S} 1$ ).

Beehives of the sampled bee species were respectively found established on a plant species diversity ranging from 4 to 8 species. Meliponula ferruginea was identified as the bee species establishing beehives on the highest diversity of plant species (i.e. 8 species), followed by M. togoensis and $M$. bocandei with 7 species each one. Beehives of $H$. gribodoi were encountered on 6 plant species while those of $A$. mellifera were generally found established on trees of 4 plant species. However, most of the beehives of A. mellifera, M. togoensis and $M$. bocandei, were recorded in the cavities of Dialium guinneense's trees. In contrast beehives of $H$. gribodoi, were registered in high quantities on trees of Manilkara multinervis. No beehive of this bee species was observed on Dialium guinneense while the highest number of beehives of $M$. ferruginea was found on trees of Cynometra megalophylla.

Relationship between the diameter at breast height of trees, the nesting choice of bees and the honey exploitation by chimpanzees

Bee species recorded in this study were found nesting in cavities of trees with a DBH ranging from 15 to $87.3 \mathrm{~cm}$. Meliponula bocandei was found nesting in trees with a high DBH (mean DBH: $52.5 \mathrm{~cm} \pm 3.6, \mathrm{n}=15$ ) while $H$. gribodoi nested in trees with the lowest DBH (mean DBH: $39.6 \mathrm{~cm}$ $\pm 3.7, \mathrm{n}=46$ ). However, no significant difference was found between the mean DBH of nesting trees of all bee species (Kruskal-Wallis test: $\chi^{2}=6.41, \mathrm{df}=4, \mathrm{p}>0.05$ ). Nevertheless, Mann-Whitney pairwise test showed a significantly difference in the DBH of nesting trees between A. mellifera and $M$. bocandei $(\mathrm{U}=37, \mathrm{p}<0.05)$, between $M$. bocandei and $H$. gribodoi $(\mathrm{U}=54, \mathrm{p}<0.05)$ and between $M$. togoensis and $M$. bocandei $(\mathrm{U}=90.5, \mathrm{p}<0.05)$ (Table $\mathrm{S} 2)$. Finally, no significant difference was found in the DBH of nesting trees with beehives identified as exploited or not by chimpanzees (Mann-Whitney test: $\chi^{2}=894.5, \mathrm{df}=1, \mathrm{p}>0.05$ ) (Table S3).

The highest value of beehive's height was observed in A. mellifera $(6.3 \mathrm{~m} \pm 1 ; \mathrm{n}=19)$ followed by $M$. bocandei $(5.9 \mathrm{~m}$ $\pm 0.7 ; \mathrm{n}=15)$, M. ferruginea $(5.3 \mathrm{~m} \pm 0.7 ; \mathrm{n}=21), M$. togoensis ( $4.9 \mathrm{~m} \pm 0.8 ; \mathrm{n}=13)$ and H. gribodoi $(3.8 \mathrm{~m} \pm 0.3 ; \mathrm{n}=46)$ (Table $\mathrm{S} 2)$. Results also showed that chimpanzees have an exploitation preference of $A$. mellifera low height's beehives. Indeed, it is only in this species that a significant difference was found between the height of exploited beehives and non-exploited beehives (Mann-Whitney test: $\chi^{2}=2, \mathrm{df}=1, \mathrm{p}<0.05$ ) (Table S4).

\section{Status of nesting trees (dead or living) and nesting place on trees}

All the beehives of A. mellifera and M. ferruginea were found in cavities of living trees trunks, while only those of $H$. gribodoi beehives were observed in all the considered parts of trees. Meliponula bocandei and M. togoensis were both found in only two parts of trees (i.e. trunks of living trees and dead trees) (Table 4).

Table 4. Relative abundance of bee species' beehives found on living trees and dead trees.

\begin{tabular}{lcccc}
\hline \multirow{2}{*}{ Bee species } & \multicolumn{3}{c}{ Relative abundance of beehives on parts of trees in brackets $(\%)$} \\
\cline { 2 - 5 } & Trunks of living trees & $\begin{array}{c}\text { Dead parts of living } \\
\text { trees trunks }\end{array}$ & $\begin{array}{c}\text { Dead branches of } \\
\text { living trees }\end{array}$ & Dead trees \\
\hline Apis mellifera & $19(100)$ & 0 & 0 & 0 \\
Hypotrigona gribodoi & $4(8.89)$ & $9(20)$ & $14(30.43)$ & $19(42.22)$ \\
Meliponula bocandei & $14(93.33)$ & 0 & 0 & $1(6.67)$ \\
Meliponula ferruginea & $21(100)$ & 0 & 0 & 0 \\
Meliponula togoensis & $11(84.62)$ & 0 & 0 & $2(15.38)$ \\
\hline
\end{tabular}




\section{Discussion}

In this study, we found that chimpanzees of the Comoé National Park exploited all the five species of arboreal social bees which were recorded in three forest types surveyed during the present study. However, there was some evidence the stingless bees (H. gribodoi, M. ferruginea, M. bocandei, $M$. togoensis) are more exploited than the honeybees $(A$. mellifera). This observation could probably be explained the by the aggressive defense strategy adopted by the honeybees to secure their beehives and honey. Indeed, African honeybees are notorious for defending their beehive through aggressive stinging - the stings are too painful for many animals that they can't withstand for long time (Hodgson et al., 2010). In contrast, stingless bees are recognized to mainly build passive defenses for their beehives such as thick walls of mud and wax. The main strategy they use to make their beehives inaccessible is to build them up to one meter underground (Tornyie \& Kwapong, 2015). However, none of these passive defense systems were found in the stingless bees of the CNP. Indeed, they only build thin wax wall or used thin cracks as entrance to their arboreal beehives on one hand or buildt heir beehives on high height branches (personal observation). In the stingless bees of the CNP, only $H$. gribodoi was seen with an aggressive behavior against the disturbance of their beehives. This species was not found stinging but workers invade the attacking by targeting all his orifices such as ears, eyes, mouth, nostrils (case of a disturbance caused by human) in order to destabilize him (personal observation).

A mean density of 2.4 beehives/ha was found within the surveyed habitats. This density was found higher than those reported before in Brazil (Siqueira et al., 2012) and Ghana (Tornyie \& Kwapong, 2015). However, we can assume that the observed range of densities (i.e $1.4-2.4$ beehives/ ha) was underestimated, due to human error in detecting beehives. Indeed, the detection of bee beehives in natural ecosystems, especially in forests is difficult and may affect the assessment of their abundance as suggested by Dorazio and Connor (2014). Moreover, the bee beehives' density within habitat seems to depend on the habitat type, the availability and diversity of potential nesting trees. In fact, high beehives densities were found in forests with a high plant specific richness (e.g. high floral resource for bees) and large DBH trees (i.e. the forest island). In contrast, a relatively low density of beehives was observed in the gallery forest which was found mainly dominated by one plant species (Cynometra megalophylla). These results are in line with those of Eltz et al. (2002) and Roubik (2006), who showed that the uneven distribution of bee species across habitats may be explained by various factors including food resources for bee foraging and the availability of suitable nesting places. In the present study, this is well demonstrated by the highest beehive density and the important number of chimpanzees' honey exploitation tools found in the mature forest island in comparison to the other habitats. Finally, one of the important reasons of this observed density can be the adaptability of bee species to habitat types. Indeed, Hypotrigona gribodoi and $M$. ferruginea had the highest number beehives in the surveyed habitats, with M. ferruginea as the most exploited bee species by the CNP's chimpanzees. These observations can be explained by the fact that this species build beehive types adapted to various type of habitats including disturbed ones (Hamisi, 2016). In addition, the high number of tools found under the beehives of $M$. ferruginea can also be explained by wide distribution of this species (e.g. high abundance within habitats). Moreover, H. gribodoi was identified as the species with the highest monospecific nesting aggregation on the same tree, suggesting (i) the absence of an intra-specific nesting competition in this species (Nkoba et al., 2012), (ii) the poor ability of this species in locating new nesting places by its scout bees (Eltz et al., 2003) or (iii) its short flight ability and dispersion across fragmented habitats (Araújo et al., 2004).

As reported by Cortopassi-Laurino et al. (2009), the present study revealed that the most used trees used by the bees to beehive in CNP belong to the Leguminosae's family. In contrast, Nkoba et al. (2012) identified the family Euphorbiaceae as the mostly nested plant species by stingless bee species in Kakamega forest. At the plant species level, Dialium guinneense, Manilkara multinervis and Cynometra megalophylla were found with the highest number of beehives in their cavities. The highest beehive number was found on Dialium guinneense probably due to the structure of this tree. The suitability of this species as nesting substrate may be related to relatively medium size of their trunks which very often have cavities. Similar tendency was reported by Kajobe (2007) where M. ferruginea seemed to have some selectivity preferences for Parinari excelsa. In fact, as suggested by Hubbell and Johnson (1977), bee species are opportunistic in selecting nesting place and generally use tree species presenting cavities with correct dimensions and purpose. However, our result contrasts with Nkoba et al. (2012), who observed a little selectivity within four Meliponini species in the Kakamega forest in Kenya for a nesting trees preference.

Arboreal bee species, in the present study, were found nesting in cavities of trees with a DBH range from 15 to $87.3 \mathrm{~cm}$, in agreement with the results of several authors (Darchen, 1972; Eltz et al., 2003; Venturieri, 2009; Tornyie $\&$ Kwapong, 2015). Bee species were found choosing nesting trees based on the presence of cavities in the trunk and the size of the DBH of the plant species. Furthermore, the size of these cavities and their respective location on trees were found determinant in the establishment of beehives. However, the exploitation of beehives by chimpanzees was not plant species DBH size dependent. Some bee species (A. mellifera and $M$. bocandei) were found nesting very high on trees. On the other hand, H. gribodoi had the lowest mean height of beehives and also a lowest number of honey exploitation tools found under its beehives. This is probably due to the small size of this species on one hand and the difficulty in locating the small cavities of its beehives. 
Most of the encountered bee species (M. bocandei, M. ferruginea, M. togoensis and A. mellifera) where found nesting preferentially in trunks of living trees; whiles the beehives of $\mathrm{H}$. gribodoi were mostly found in dead parts of trees. However, beehives located in the cavities trees trunks were found more exploited by chimpanzees than those found on branches, probably due to the important quantities of honey generally found in trunks (Michener, 2000). The choice of living or dead trees to beehive is may be a defense strategy of the colony. Indeed, according to Roubik (1989) and Martins et al. (2004), a strategy of defense against predators and parasites, guarantee of a longevity of colonies, in some Meliponini is the establishment of beehives on living trees.

In conclusion, beehives density within habitats was found depending on the habitat type, the availability and diversity of the nesting trees. Arboreal bee species were found choosing their nesting trees based on the presence of cavities in the trunk and the size of the DBH of the plant species. Frequent exploitation of stingless bee's honey by chimpanzees was observed, except for H. gribodoi. Meliponula ferruginea was the most exploited species by chimpanzees in the Comoé National Park. These primates don't have a particular choice for beehives when we consider the DBH of trees nesting but they tend to exploit $A$. mellifera nests with low height. Complementary researches are needed to assess the influence of the quantity and quality of honey on one hand and the beehive's structure on the other hand, in their exploitation choice by chimpanzees. Data should also be collected on the involvement of the five bee species in the pollination of trees (e.g. production of fruits consumed by chimpanzees), through the melissopalynology.

\section{Acknowledgements}

This work was partly supported by a grant of the Rufford foundation (ID 24051-1) and the Comoé Chimpanzee Conservation Project. We also would like to thank the agency in charge of Ivorian parks and reserve (the so called OIPR) for the authorization access and the research permit in the Comoé National Park. We are grateful the anonymous reviewers for the comments and edits on a first version of this manuscript. Thank you to our field assistants (Sylvain, Ibrahim, Moussa and Abou) and to all the staff of Comoé National Park Research Station in Ecology (Koffi, Lakado, Richard, David and Inza) for their support during our stay.

\section{Authors' Contributions}

Nicodénin Angèle SORO: Investigation, Data collection, Data curation and Writing the original draft.

Juan LAPUENTE: Investigation, Data collection, Methodology, conceptualization, writing, review and editing.

N'golo Abdoulaye KONE, Kolo YEO and Souleymane KONATE: Conceptualization, Methodology, writing, review and editing

\section{References}

Araújo, E.D., Costa, M., Chaud-Netto, J. \& Fowler, H.G. (2004). Body size and flight distance in stingless bees (Hymenoptera: Meliponini): inference of flight range and possible ecological implications. Brazilian Journal Biology, 64 : 563-568. doi: 10.1590/S1519-69842004000400003

Aubréville, A. (1949). Climats, forêts et désertification de l'Afrique tropicale. Société d'Editions Géographiques, Maritimes et Coloniales, Paris, 89p.

Boesch, C.C., Head, J. \& Robbins, M.M. (2009). Complex tool sets for honey extraction among chimpanzees in Loango National Park, Gabon, Journal of Human Evolution xxx (2009) 1-10.

Campbell, G., Kuehl, H., Kouamé, P.N.G. \&Boesch, C. (2008). Alarming decline of West African chimpanzees in Côte d'Ivoire. Current Biology, 18: 903-904.

Cortopassi-Laurino, M., Alves, D.A. \& Imperatriz-Fonseca, V.L. (2009). Árvores neotropicais, recursos importantes para a nidificação de abelhas sem ferrão (Apidae, Meliponini). Mensagem Doce, 100: 21-28.

Crickette M. S \& David B. M (2008). Flexible and Persistent Tool-using Strategies in Honey-gathering by Wild Chimpanzees. Int J Primatol, 30 :411-427.

Darchen, R. (1972). Ecologie de quelques trigones (Trigona sp.) de la Savane de Lamto (Cote d'Ivoire). Apidologie 3: 341-367.

Deblauwe, I., Dupain, J., Nguenang, G.M., Werdenich, D. \&VanElsacker, L. (2003). Insectivory by Gorilla gorillagorilla in Southeast Cameroon. International Journal of Primatology, 24(3): 493-502.

Dorazio, R.M \& Connor, E.F. (2014). Estimating abundances of interacting species using morphological traits, foraging guilds, and habitat. PloS One, 9(4), e94323.

Eardley C.D. (2004). Taxonomic revision of the African stingless bees (Apoidea: Apidae: Apinae: Meliponini). African Plant Protection, 10: 63-96.

Eardley, C., Kuhlmann, M \& Pauly, A. (2010). The Bee Genera and Subgenera of Sub-Saharan Africa. Abc Taxa, 7: 145.

Eltz, T., Bruhl C.A., Van Der Kaars, S., \&Linsenmair K.E. (2002). Determinants of stingless bee beehive density in lowland dipterocarp forests of Sabah, Malaysia. Oecologia, 131: 27-34. doi: 10.1007/s00442-001-0848-6

Eltz, T., Brühl, C.A., Imiyabir, Z \&Linsenmair, K.E. (2003). Nesting and beehive trees of stingless bees (Apidae: Meliponini) in lowland dipterocarp forests in Sabah, Malaysia, with implications for forest management. Forest Ecology and Management, 172: 301-313. doi: 10.1016/ S0378-1127(01)00792-7

Goodall, J. (1986). The Chimpanzees of Combe: Patterns of Behavior. Cambridge, MA: Harvard University Press. 
Hamisi, I. (2016). Diversity, status and threats to stingless bees (Apidae: Meliponini) of Ipembampazi forest, reserve, Tabora - Tanzania. Master of Science in ecosystem science and management of Sokoine University of agriculture. Morogoro Tanzania, $70 \mathrm{p}$.

Hammer, O., Harper, D.A.T., \& Yan, P.D.R. (2001). PAST: Paleontological Statistics Software Package for Education and Data Analysis. Palaeontologia Electronica, 4(1): 9 p.

Hennenberg, K.J. (2005). Vegetation ecology of forestsavanna ecotones in the Comoé National Park (Ivory Coast): Border and ecotone detection, core-area analysis, and ecotone dynamics. Rostock, Germany: Dissertation Thesis, 108 p.

Hodgson, E.W. Cory, A.S., Roe, A.H. \& Downey, D. (2010). Africanized Honey Bees. Utah State University Extension and Utah Plant Pest Diagnostic Laboratory, $4 \mathrm{p}$.

Hoppe-Dominik, B. (1991). Distribution and status of chimpanzees (Pan troglodytes verus) on the Ivory Coast. Primate Report, 31: 45-57

Hubbell, S.P. \& Johnson, L.K. (1977). Competition and beehive spacing in a tropical stingless bee community. Ecology, 58: 950-963. doi: 10.2307/1936917

Kajobe, R. (2007). Nesting biology of equatorial Afrotropical stingless bees (Apidae; Meliponini) in Bwindi Impenetrable National Park, Uganda. Journal of Apicultural Research and Bee World, 46(4): 245-255. doi: 10.1080/00218839.2007.11101403

Kouassi, K.E., Sangne, Y.C. \& Dibi, N.H. (2014). Typologie de la végétation par une approche de signature spectrale dans le sud du Parc national de la Comoé (nord-est Côte d'Ivoire). European Scientific Journal, 10(36): 1857-7881.

Lapuente J., Hicks, T.C. \& Linsenmair, K.E. (2016). Fluid dipping technology of chimpanzees in Comoé National Park, Ivory Coast. American Journal of Primatology, 9999:e22628. doi: 10.1002/ajp.22628

Lauginie, F. (2007). Conservation de la nature et aires protégées en Côte d'Ivoire. NEI/Hachette et Afrique Nature, Abidjan, $\mathrm{xx}+668 \mathrm{pp}$.

Marchesi, P., Marchesi, N., Fruth, B. \& Boesch, C.C. (1995). Census and distribution of chimpanzees in Côte D'Ivoire. Primates, 36: 591-607.

Martins, C. F., Cortopassi-laurino, M., Koedam, D. \& Imperatrizfonseca, V. L. (2004). Tree Species Used for Nidification by Stingless bees in the Brazilian Caatinga (SERIDÓ, PB; JOÃO CÂMARA, RN). Biota Neotropica, 4(2): 1-8.

McBeath, N.M. \& McGrew, W.C. (1982). Tools used by wild chimpanzees to obtain termites at Mt. Assirik, Senegal: the influence of habitat. Journal of Human Evolution, 11: 65-72.

McGrew, W. C. (2001). The other faunivory: primate insectivory and early human diet. In: Stanford CB, Bunn HT, editors. Meat-Eating and Human Evolution. Oxford: Oxford University
Press. 160-178 p.

McGrew, W.C. (1992). Chimpanzee material culture. Implications for human evolution. Cambridge University Press, Cambridge, UK.

McLennan, M.R. (2011). Tool-use to obtain honey by chimpanzees at Bulindi: new record from Uganda. Primates 52: 315-322. DOI 10.1007/s10329-011-0254-6

Michener, C.D. (2000). The Bees of the World. Johns Hopkins Press, Baltimore.

Mühlenberg, M., Galat-Luong, A., Poilecot, P., SteinhauerBurkart, B., \& Kühn, I. (1990). L'importance des ilôts forestiers de savane humide pour la conservation de la faune de forêt dense en Côte d'Ivoire. Revue Ecologie (Terre Vie), 45: 197-214.

Nkoba, K., Raina, S.K., Muli, E., Mithofer, K. \&Mueke, J. (2012). Species richness and beehive dispersion of some tropical meliponine bees (Apidae: Meliponinae) in six habitat types in the Kakamega forest, western Kenya. International Journal of Tropical Insect Science, 32(4):194-202. doi: 10.10 17/S1742758412000355

O’Malley, R.C. \& Power, M.L. (2012). Nutritional Composition of Actual and Potential Insect Prey for the Kasekela Chimpanzees of Gombe National Park, Tanzania. American Journal of Physical Anthropology, 149: 493-503.

Pavithra, P.N., Shankar, M.R. \& Prakash, J. (2013). Nesting Pattern Preferences of Stingless Bee, Trigona iridipennis Smith (Hymenoptera: Apidae) in Jnanabharathi Campus, Karnataka, India. International Research Journal of Biological Sciences, 2(2): 44-50.

Potts, S.G., Vulliamy, B., Roberts, S., O’Toole, C., Dafni, A., Ne'eman, G., Willmer, P. (2005). Role of nesting resources in organising diverse bee communities in a Mediterranean landscape. Ecological Entomology, 30: 78-85.

Pruetz, J.D. (2006). Feeding Ecology in Apes and Other Primates. Ecological, Physical and Behavioral Aspects, ed. G. Hohmann, M. M. Robbins, and C. Boesch. Cambridge University Press, 161-182 p.

Redford, K.H. (1987). Ants and termites as food. Patterns of mammalian myrmecrophagy. Current mammalogy. Genoways, ed. New York, Plenum Press, 1: 349-399.

Roubik, D.W. (1989). Ecology and natural history of tropical bees. Cambridge University press, Cambridge, New York. 514 p.

Roubik, D.W. (2006). Stingless bee nesting biology. Apidologie, 37: 124-143. doi: 10.1051/apido:2006026

Sanz, C.M. \& Morgan, D.B. (2007). Chimpanzee tool technology in the Goualougo Triangle, Republic of Congo. Journal of Human Evolution, 52: 420-433. doi: 10.1016/j. jhevol.2006.11.001 
Sanz, C.M. \& Morgan, D.B. (2009). Flexible and Persistent Tool-using Strategies in Honey-gathering by Wild Chimpanzees. International Journal of Primatology 30: 411-427. doi: 10.1007/ s10764-009-9350-5

Siqueira, E.N.L., Bartelli, B.F., Nascimento, A.R.T. \& Nogueiraferreira, F.H. (2012). Diversity and Nesting Substrates of Stingless Bees (Hymenoptera, Meliponina) in a Forest Remnant. Psyche, 9 p. doi: 10.1155/2012/370895

Sommer, V., Buba, U., Jesus, G. \& Pascual-Garrid, A. (2012). Till the last drop: honey gathering in Nigerian Chimpanzees. Ecotropica, 18: 55-64.

Tornyie, F. \&Kwapong, P.K. (2015). Nesting ecology of stingless bees and potential threats to their survival within selected landscapes in the northern Volta region of Ghana. John Wiley \& Sons Ltd, African Journal of Ecology, 53:398405. doi: 10.1111/aje. 12208

Tutin, C.E.G., Ham, R. \&Wrogemann. D. (1995). Tool use by chimpanzees (Pan t. troglodytes) in the Lope Reserve, Gabon. Primates, 36: 181-192.

van Schaik, C.P. (2004). Among orangutans. Red apes and the rise of human culture. Belknap Press of Harvard University Press, Cambridge, MA.

Venturieri, G.C. (2009). The impact of forest exploitation on Amazonian stingless bees (Apidae, Meliponini). Genetics and Molecular Research, 8(2): 684-689.

\section{Supplementary Material}

Table S1: Relative abundance of plant species on which arboreal social bees' beehives were observed.

\begin{tabular}{|c|c|c|c|c|c|c|}
\hline Family & Tree species & MFI & SFI & GF & Total & $\begin{array}{l}\text { Relative } \\
\text { abundance (\%) }\end{array}$ \\
\hline \multirow[t]{4}{*}{ Leguminoseae } & Dialium guinneense Willd., 1796 & $69 / 15 / 10$ & $21 / 7 / 3$ & $41 / 2 / 1$ & $131 / 24 / 14$ & 26.37 \\
\hline & Albizia zygia J.F. Macbr., 1919 & $19 / 1 / 0$ & $1 / 0 / 0$ & $5 / 0 / 0$ & $25 / 1 / 0$ & 1.1 \\
\hline & Tamarindusindica L., 1753 & $7 / 3 / 3$ & $1 / 1 / 1$ & 0 & $8 / 4 / 4$ & 4.4 \\
\hline & Cynometra megalophylla L., 1753 & $5 / 1 / 1$ & 0 & $973 / 5 / 5$ & $978 / 6 / 6$ & 6.59 \\
\hline \multirow[t]{2}{*}{ Ulmaceae } & Celtisintegrifolia Lam., 1983 & $119 / 10 / 0$ & $28 / 0 / 0$ & $36 / 2 / 1$ & $183 / 12 / 1$ & 13.19 \\
\hline & Liana & 0 & 1 & 0 & 1 & 1.1 \\
\hline Combretaceae & Antiaris toxicaria Lesch., 1810 & $10 / 1 / 0$ & $3 / 0 / 0$ & $3 / 0 / 0$ & $16 / 1 / 0$ & 1.1 \\
\hline \multirow[t]{2}{*}{ Moraceae } & Ficus ingens (Miq.) Miq., 1867 & $6 / 0 / 0$ & $6 / 1 / 0$ & 0 & $12 / 1 / 0$ & 1.1 \\
\hline & Ficus sp. & $17 / 1 / 0$ & $9 / 0 / 0$ & 0 & $26 / 1 / 0$ & 1.1 \\
\hline Verbenaceae & Vitex sp. & $5 / 2 / 1$ & 0 & $4 / 2 / 0$ & $9 / 4 / 1$ & 4.4 \\
\hline Ebenaceae & Diospyros mespiliformis Hochst. ex A.DC., 1844 & $42 / 1 / 0$ & $61 / 0 / 0$ & $14 / 0 / 0$ & $117 / 1 / 0$ & 1.1 \\
\hline Sterculiaceae & Cola gigantean A. Chev., 1908 & $7 / 0 / 0$ & $36 / 1 / 0$ & $9 / 0 / 0$ & $52 / 1 / 0$ & 1.1 \\
\hline Total & & $516 / 55 / 19$ & $252 / 22 / 6$ & $1113 / 14 / 8$ & $1881 / 91 / 33$ & 100 \\
\hline
\end{tabular}

Abbreviations: MFI = mature forest island; SFI = secondary forest island, GF = Gallery Forest

Data in cells are reported as follows: total individual species-specific observed trees/ number trees on which bee nests were found/ number of trees on which bee nest exploited by chimpanzees were found.

PS: The lianas were not taken into account in the total of individual species-specific observed trees and in the number of trees on which bee nest exploited by chimpanzees were found. The $\mathrm{p}$ values compare the total number of observed trees and the number of trees on which bee nest exploited by chimpanzees were found. 
Table S2: Characteristics of beehives and the nesting trees of the encountered bee species.

\begin{tabular}{lllll}
\hline Bees species & DBH range $(\mathrm{cm})$ & Mean DBH $(\mathrm{cm})$ & $\begin{array}{l}\text { Range of beehives’ } \\
\text { height }(\mathrm{m})\end{array}$ & $\begin{array}{l}\text { Mean height of } \\
\text { beehives }(\mathrm{m})\end{array}$ \\
\hline Apis mellifera & $31.2-51.6$ & $39.9 \pm 1.9$ & $1-15$ & $6.3 \pm 1$ \\
Meliponula togoensis & $28.7-67.8$ & $47.1 \pm 5.4$ & $2-11$ & $4.9 \pm 0.8$ \\
Meliponula bocandei & $32.2-87.3$ & $52.5 \pm 3.6$ & $1.2-15$ & $5.9 \pm 0.7$ \\
Meliponula ferruginea & $15-75.5$ & $45.9 \pm 4.1$ & $2.3-9$ & $5.3 \pm 0.7$ \\
Hypotrigona gribodoi & $19.7-60.5$ & $40.1 \pm 2$ & $0.6-7$ & $3.8 \pm 0.3$ \\
\hline
\end{tabular}

Table S3: Range and mean of DBH of the exploited and non-exploited beehives in the recorded bee species.

\begin{tabular}{llllll}
\hline \multirow{2}{*}{ Bees species } & \multicolumn{2}{l}{ DBH range $(\mathrm{cm})$} & & Mean DBH $(\mathrm{cm})$ & \\
\cline { 2 - 3 } \cline { 5 - 6 } & $\begin{array}{l}\text { Exploited beehives' } \\
\text { trees }\end{array}$ & $\begin{array}{l}\text { Non-exploited } \\
\text { beehives' trees }\end{array}$ & & $\begin{array}{l}\text { Exploited beehives' } \\
\text { trees }\end{array}$ & $\begin{array}{l}\text { Non-exploited } \\
\text { beehives' trees }\end{array}$ \\
\hline Apis mellifera & $39.5-51.6$ & $31.2-49$ & $45.6 \pm 3.5$ & $38.3 \pm 2.2$ \\
Meliponula togoensis & $22.3-54.1$ & $28.7-67.8$ & $39.4 \pm 0.8$ & $51.95 \pm 7.7$ \\
Meliponula bocandei & $32.2-87.3$ & $41.4-65.3$ & $52.2 \pm 5.5$ & $53.1 \pm 4.1$ \\
Meliponula ferruginea & $28.7-68.8$ & $15-75.5$ & $47.2 \pm 4.7$ & $43.3 \pm 8.6$ \\
Hypotrigona gribodoi & $19.7-47.8$ & $21.7-60.5$ & $33.8 \pm 8.1$ & $40.7 \pm 2.1$ \\
\hline
\end{tabular}

Table S4: Height of exploited beehives or not by chimpanzees.

\begin{tabular}{llllll}
\hline \multirow{2}{*}{ Bees species } & \multicolumn{2}{l}{ Range of beehives heights $(\mathrm{m})$} & & \multicolumn{2}{l}{ Beehives meanheights $(\mathrm{m})$} \\
\cline { 2 - 3 } \cline { 5 - 5 } & Exploited beehives & $\begin{array}{l}\text { Non-exploited } \\
\text { beehives }\end{array}$ & & Exploited beehives & $\begin{array}{l}\text { Non-exploited } \\
\text { beehives }\end{array}$ \\
\hline Apis mellifera & $1-5$ & $2.5-15$ & $2.1 \pm 1$ & $7.7 \pm 0.9$ \\
Meliponula togoensis & $2.5-11$ & $2-7$ & $5 \pm 1.7$ & $4.8 \pm 6.1$ \\
Meliponula bocandei & $3.5-7$ & $1.2-15$ & $6.8 \pm 0.9$ & $4.4 \pm 1$ \\
Meliponula ferruginea & $2.7-14$ & $2.3-9$ & $5.9 \pm 0.9$ & $4 \pm 0.9$ \\
Hypotrigona gribodoi & $2.5-5$ & $0.6-7$ & $4.8 \pm 1.3$ & $3.8 \pm 0.3$ \\
\hline
\end{tabular}

